Araştırma Makalesi

\title{
Gelin-Kaynana İletişiminin Niteliğini Belirleyen Kültürel Etmenler
}

\author{
Tebrike Kaya (Dr. Öğr. Üyesi) \\ Beykent Üniversitesi İletişim Fakültesi \\ tebrikekaya@beykent.edu.tr \\ Orcid: 0000-0002-4348-3861
}

Başvuru Tarihi: 13.09.2018

Yayına Kabul Tarihi: 27.12.2018

Yayınlanma Tarihi: 21.01.2019

\section{Öz}

Aile deyince akla hemen anne-baba ve çocuklardan oluşan bir grup gelir. Fakat Türk ailesinin tecrübesi bundan farklıdır. Türk aileleri aynı evi paylaşmasalar da akraba oldukları ailelerle sıkı bir iletişim içindedirler. Türkiye'de kan bağı yoluyla akraba olmanın dışında, evlilik yoluyla edinilen akrabalık ilişskileri de çok önemlidir. Ataerkil düzenin hüküm sürdügü toplumlarda evli olmak, yetişkin kadınlar ve erkekler için bir gerekliliktir. Kadın açısından evli olmanın anlamı daha da derindir. Zira, ailenin ait olduğu toplumsal sınıf erkeğin toplumsal konumuna göre belirlendiği için kadın açısından evlilik yeni bir kimlik edinmek anlamına gelmektedir. Ancak, kadının evlilik yoluyla dâhil olduğu soy grubu içinde gelin olarak kabul görmesi, kayınvalidesine uyumlu davranmasıyla yakından ilişkilidir. Türk toplumunda, kız çocuklarına ideal gelin-kayınvalide ilişkisinin anne-kız ilişkisi gibi olması gerektiği öğretilir. Buna karşın gerek medya temsillerinde gerekse gündelik yaşamda iyi geçinen bir gelinkaynana ikilisi görmek neredeyse imkânsızdır. Bu araştırma, gelin-kaynana arasında çatışma yaratan kültürel faktörleri ortaya koymak amacıyla yapılmıştır. Niteliksel yöntemle yapılan bu araştırmanın bulguları, gelin ve kayınvalide olan toplam on iki kadınla derinlemesine görüşme yaparak elde edilmiştir. Araştırmanın sonucuna göre gelin-kaynana iletişiminin niteliği büyük ölçüde kayınvalidenin tutum ve davranışlarına göre șekillenmektedir. Gelin-kaynana ilişkisinin anne-oğul arasındaki ilişkinin niteliğiyle yakından ilişkili olduğu anlaşılmaktadır. Kayınvalidenin maddi açıdan oğlunun desteğine muhtaç olması, gelin-kaynana arasında sorun çıkmasına neden olmaktadır. Ayrıca, kadınların doğup büyüdüğü sosyal çevre, ekonomik durum, eğitim durumu ve önyargılar gelin-kaynana iletişiminin niteliğini önemli ölçüde etkilemektedir.

Anahtar Kelimeler: Aile, Evlilik, İletişim, Kültür, Kaynana-Gelin. 
Research Article

\title{
Cultural Factors Determining the Communication Between Daughter-in-Law and Mother-in-Law
}

\author{
Tebrike Kaya (Asst. Prof. Dr.) \\ Beykent University Faculty of Communication \\ tebrikekaya@beykent.edu.tr \\ Orcid: 0000-0002-4348-3861
}

Date Received: 13.09 .2018

Date Accepted: 27.12 .2018

Date Published: 21.01.2019

\begin{abstract}
When the term "family" is heard, a group consisting of father, mother and children comes to mind. However, the experience of the Turkish family is different. Even if they do not share the same household, the Turkish families are closely connected to related families. Apart from being related by bloodline, kinship relations acquired through marriage are also very important in Turkey. In communities where patriarchal rule prevails, being married is a necessity for adult women and men. The meaning of being married for a woman is even more profound. Because, while the social class to which the family belongs to is determined according to the social position of the man, in terms of women marriage means acquiring a new identity. However, the acceptance of a woman as a daughter-in-law in the pedigree group in which she gets included through marriage is related to how well she gets along with her mother-in-law. It is taught to girls in Turkish society that the ideal relationship between the daughter-in-law and the mother-in-law should be like a mother-daughter relationship. On the other hand, it is almost impossible to see in representations or in daily life a daughter-in-law mother-in-law duo who gets on well. This study was conducted in order to reveal the cultural factors that create conflict between daughter-in-law and mother-in-law. The findings of this study with qualitative methods were obtained by in-depth interviews with a total of twelve women who were daughter-in-law and mother-in-law. According to the results of the study, the quality of the communication between daughter-in-law and motherin-law is largely shaped by the attitudes and behaviors of the mother-in-law. In addition, the relationship between daughter-in-law and mother-in-law is directly related to the quality of the relationship between mother and son. The fact that the mother-in-law is financially dependent on the support of her son causes problems. As a result, the social environment in which women are born and raised, economic status, educational status and prejudices affect the quality of the communication between daughter-in-law and mother-in-law.
\end{abstract}

Keywords: Family, Marriage, Communication, Culture, Daughter-İn-Law, Mother-İn-Law. 


\section{Giriş}

İnsanlar çoğunlukla bir aile içerisine doğarlar ve aileyi yaşamın vazgeçilmez bir parçası olarak görürler. Toplumu oluşturan en küçük birim olan aile, toplumsal ve bireysel önemi dolayısıyla her zaman sosyal bilimlerin araştırma konuları arasında olmuştur. Aile ile ilgili pek çok araştırma ve tanım yapılmıștır. Ancak, Batılı kaynaklar tarandığında, tanımların çekirdek aile üzerinde yoğunlaştığı görülmektedir. $\mathrm{Bu}$ kavramı ilk kullanan araştırmacılardan biri olan Murdock (1949) çekirdek aileyi, aynı yerde ikamet eden, aralarında toplumca onaylanmış cinsel ilişkinin olduğu evli bir çift ve onların çocuklarından oluşan bir grup olarak tanımlar. Cheal (2002) ise aileyi evlilik yoluyla edinilen akrabalık ilişkilerinin önemini vurgulayacak şekilde "nesiller boyu yakın ilişki içinde olduğu düşünülen insan grubu” olarak tanımlamıştır.

Çekirdek ailenin oluşması, tüm dünya kültürlerinde olduğu gibi Türk kültüründe de evlilik töreniyle başlar. Evlenen çiftler, evlilik vasıtasıyla hem yeni bir çevre hem de yeni akrabalık ilişkileri kazanırlar (Tezcan, 2000, 35). Farklı toplumlarda, farklı şekillerde tanımlanan ve anlamlandırılan akrabalık terimleri, ait olduğu toplumda akrabalara nasıl davranılacağını belirler. Dünyanın farklı bölgelerinde yaşayan insanların akrabalık ilişkileri incelendiğinde, akraba olanlar arasındaki yakınlığın ve saygının her toplumda farklı olduğu görülmektedir. Örneğin Türkiye'de babasoyunun daha prestijli olduğu kabul edilir ve evlilik yoluyla oluşan akrabalık ilişkileri nesiller boyu sürdürülür. Nitekim Kandiyoti (1974) Türk ailelerinin aynı evi paylaşmasalar dahi akraba oldukları ailelerle sıkı bir iletişim içinde olduklarını ve ilk bakışta çekirdek aile gibi görünen ailelerin pratikte geniş aile biçiminde yaşamaya devam ettiklerini, dolayısıyla Türk ailesinin işlevsel olarak geniş aile özellikleri taşıdığını belirtmektedir.

Türkiye'de evlilik yoluyla genişleyen akrabalık sistemi içindeki ilişkilerin en hassas ve sorunlara en açık olanı gelin-kaynana ilişkisidir. Ailenin devamlılığının sağlanması açısından, gelin ve kayınvalidenin birbiriyle anlaşması çok önemlidir. Zira yeni kurulan çekirdek aile ve erkek tarafı arasındaki sorunlar genellikle gelin kaynana anlaşmazlığından ortaya çıkmaktadır. Anne ve oğul arasındaki güçlü bağ, yeni gelinin aileye katılmasıyla zayıflayabilmekte ve bu durum anneye duyulan ilgide değişiklik meydana getirdiği için kıskançlığa neden olabilmektedir. Yeni gelinin aileye katılması, kayınvalidenin iş yükünün hafiflemesine, gezmeye daha çok vakit ayırmasına ve yıllardır beklediği kaynanalık rolünü oynamasına olanak sağlaması bakımından olumlu bir değişikliktir. Fakat bazı durumlarda yeni gelin, kayınvalidenin oğlu ve ailesi üzerindeki kontrolü kaybetme korkusu yaşamasına da neden olabilmektedir (Delaney, 2018, 184).

Gündelik yaşamda, gelin-kaynana arasında yaşanan sorunlarla sıkça karşılaşılmaktadır. Buna paralel olarak gelin-kaynana ilişkileri, romanların, dizilerin ve filmlerin favori konusu olmaya devam etmektedir. Bu tür yapımlarda kayınvalideler genellikle her şeye karışan ve gelinin hayatını cehenneme çeviren bir rol üstlenirken, gelinler bütün aileyi yıkıma sürükleyen kötü kadınlar olarak temsil edilmektedir. Bu temsiller, izleyicilere gelinlerin kontrol altında tutulması gereken kadınlar olduğunu hatırlatırken, kayınvalidelerin otoriter ve kontrol edici davranışlarını meşrulaştırmaktadır. Medyanın toplumu yansıttığı ve yansıtırken yeniden ürettiği gerçeği göz önüne alındığında, gelin ve kayınvalide olan kadınların gündelik yaşamlarında pek çok sorunla karşılaşmaları kaçınılmazdır. $\mathrm{Bu}$ sorunlar, içinde yaşanan kültürün gelin ve kaynana olan kadına yüklediği 
sorumluluklarla ve bu kadınların kişisel olarak birbirlerinden ne bekledikleriyle ilişkilidir. Bu çalışmanın amacı, gelin-kaynana iletişiminin niteliğini belirleyen kültürel faktörleri ortaya koyarken, gelinlerin ve kayınvalidelerin birbirlerinden ne beklediğini açıklığa kavuşturmaktır.

\section{Kültür, İletişim ve Kültürlerarasılık}

Geniş bir anlam yelpazesine sahip olan kültür, tanımlanması güç bir kavramdır. Bu güçlük, kültür sözcüğünün çok anlamlı ve soyut bir sözcük olmasından kaynaklanır. Kültür, bir toplumun ya da bütün toplumların birikimli uygarlığı anlamında kullanıldığı gibi belli bir toplumu ifade etmek için de kullanılır. Aynı zamanda bir insan ve toplum kuramı olan kültür kavramının yüz elliden fazla tanımı vardır. Kültür, bu tanımların tek tek hiçbiri değil onların tümüdür. Güvenç (1999) sosyal antropolojinin konusunun kültür olduğunu söyleyen Tylor tarafından yapılan tanımı, kültür kuramının ana savını ortaya koyması açısından öteki kültür tanımlarından ayrı tutar. Tylor (1871) kültürü "bir toplumun üyesi olarak, insanoğlunun öğrendiği bilgi, sanat, gelenek-görenek ve benzeri yetenek, beceri ve alışkanlıkları içine alan karmaşık bir bütün" olarak tanımlamıştır (Güvenç, 1999, 101).

Kültürü, insanların yaşama biçimi olarak tanımlayan Edward T. Hall, kültürün dış dünyaya ait fenomenlerin ve uyaranların algılanmasında dahi etkili olduğunu söyler. Kültürün dil, tarih, toplumsal örgütlenme, normlar, bilgi, davranıșlar, değerler, inançlar ve ait olunan grup tarafından kabul edilen algılar gibi ortak kodları içerdiğini belirtir. Hall'a göre kültürle ilgili bilinmesi gereken üç önemli nokta vardır. Kültür öğrenilir, kültürün çeşitli yönleri birbiriyle ilişkilidir ve kültür paylaşılır. Kültür, farklı grupların sınırlarını tanımlayan, birbirinden ayıran, insanların tepkilerini ve hareketlerini programlayan, insanların yaşamak için yaptığı her şeyi kapsayan bir sistemdir (Hall ve Hall, 1983, 14).

Kültür, insanın ortaya koyduğu, içinde insanın var olduğu tüm gerçeklik demektir. Başka bir ifadeyle kültür, insanın kendisini kendi evinde gibi hissetmesini sağlayacak bir dünya olușturmasıdır. İnsanın duyduğu, düşündüğü, yaptığı, istediği şeyler, insanın yaşama biçimi, benimsediği eylem kalıpları, teknik, ekonomi, hukuk, bilim ve devlet, kısacası, insanın meydana getirdiği her şey kültürün içine girer. Örgütler, dernekler, kurum ve kuruluşlar, okullar, bunların hepsi tüm unsurlarıyla birlikte kültür ürünüdürler. İnsanlar arasındaki her çeşit karşılıklı etkileşime, her türlü yapıp yaratma alışkanlıklarına, bütün manevi ve maddesel yapitlara ve ürünlere kültür denir (Uygur, 1996, 17).

Kültür iletişimle aktarılır. Kültür gibi pek çok tanımı olan iletişim kavramı, en basit șekilde "bilgi, fikir ve duyguların simgeler yoluyla aktarılma süreci" olarak tanımlanabilir (Mutlu, 1998, 168). Her birey, çocukluğundan itibaren ait olduğu toplumun kültürünü öğrenir ve ona göre șekillenir. Bu anlamda birbirini kuşatan kültür ve iletişim arasında sıkı bir ilişki vardır. İletişim, bireylerin sosyalleşmesinin dolayısıyla kültürün taşıyıcısıdır. İletişim alanı, kuralları olan, çözümlenebilen ve araştırmacıların kişilerarası iletişimin kültürel kalıplarını kuramsal olarak ifade edebilecekleri bir alandır (Kartarı, 2001, 31).

Kültürel özellikleri farklı bireyler arasında gerçekleşen etkileşim süreci aynı zamanda bir kültürlerarası iletișim sürecidir. Aile, evlilik, ticari ve resmî kurumlarda bir arada olan farklı kültürlere mensup insanlar arasındaki etkileşim de kültürlerarası 
iletişimin konusudur (Kartarı, 2001, 182). Kültürlerarası iletişim sürecinin etkin bir şekilde gerçekleşmesini engelleyen faktörler arasında, etnikmerkezci bakış açısının yanı sıra normlar, roller, kalıp düşünceler ve önyargılar sayılabilir. Her kültür, üyelerini belirli davranış kalıplarına uymaya zorlar. Normlar olarak adlandırılan bu davranış kuralları kültürden kültüre farklılık gösterir. Bireyin ait olduğu grup içinde kendisinden beklenen davranış kalıpları ise sosyal bilimlerde rol kavramıyla ifade edilmektedir. Grup içerisinde bireylere biçilen roller de her kültürde farklıdır. Örneğin, Türk toplumunda evlat rolüne atfedilen anlam ve evlattan beklenen davranış modeli, Amerika veya Avrupa toplumlarında aynı roldeki bireyin davranış modelinden farklıdır. Bu farklılıklar, insanın doğal olarak etnikmerkezci bakış açısına sahip olması nedeniyle "doğal" karşılanmaz ve bireyin kendi kültürünün düşünce ve davranış kalıpları doğru, öteki kültürlere özgü düşünce ve davranış kalıpları yanlış olarak kabul edilir. Kültürlerarası iletişim sürecini önemli ölçüde etkileyen yanlış anlamayı önlemek için kalıp düşüncelerin ve önyargıların farkında olmak gerekir. Başka bir deyişle, kültürü farklı insanların anlaşabilmeleri için kültürlerarası iletişim yeterliliğine sahip olmaları gerekir (Kartarı, 2001, 207).

Bu noktada kalıp düşünceler ve önyargılar arasındaki farkı açıklamak gerekmektedir. Önyargı, herhangi bir gruptan bir kişiye sadece o gruba ait olması nedeniyle gösterilen muhalif ya da düșmanca tutum olarak tanımlanabilir. Önyargılar, insanlarda doğal bir eğilim olarak ortaya çıkan kategorik düşünme ve aşırı genellemeler yapma sonucunda oluşurlar. Önyargı sözcüğünün kökeni Antik döneme dayanmaktadır. Antik dönemde, önceki karar ve deneyimlere dayanan yargı anlamında kullanılan prejudicium sözcüğü, daha sonra İngilizce'de inceleme yapmadan ve üzerinde düşünmeden oluşturulmuş yargı anlamı kazanmıștır. Sözcüğe yüklenen bu iki anlam, önceden varılmış bir yargıyla birlikte, bir şeyin lehinde veya aleyhinde olmayla ilgili duyguları da içerecek şekilde kullanılmaya başlanmıştır (Allport, 1954, 23).

Kalıp düşünceleri bilișsel, önyargıları duygusal olmaları yönüyle birbirinden ayırmak mümkün olsa da gerçekte her iki kavram da bir biliş ve duygu karışımını yansıtır (Taylor ve diğerleri, 2015, 182). Kalıp düşünceler ve önyargılar arasındaki bağlantı gelin-kaynana konusuyla ilişkilendirilerek şöyle açıklanabilir. Kaynanalara karşı önyargılı olan gelinler, belleklerinde kaynanalar olarak adlandırdıkları grupla, bu gruba özgü kalıp düșünceleri birbiriyle ilișkilendirerek edindikleri olumsuz duyguyu kayınvalidelerine atfetmek eğilimindedirler. Gelinlere karşı önyargılı olan kayınvalidelerde de aynı eğilim söz konusudur. Önyargılı gelinler ve kayınvalideler birbirlerini bireysel özellikler temelinde değil grup üyelikleri temelinde peşin hükümle değerlendirirler.

\section{Türk Toplumunda Aile ve Hane Yapısı}

Türkiye'deki kırsal nüfusun geniş aile, kentsel nüfusun ise Batı'daki aile biçimine benzeyen çekirdek aile biçiminde yaşadığına dair yaygın bir düşünce vardır. Kentte yaşayan eğitimli insanlar arasında yaygın olan bu görüşe göre, kırdan kente göçün başlamasıyla kırsal aile küçülerek kentli küçük aileye dönüşmekte ve geniş aileler kente uyum sağladıkça, akrabalığın önemi azalmaktadır. Bu varsayımlar, Batı'daki sanayileşme ile ailenin değişimi arasında ilişki kuran, ancak son zamanlarda sorgulanmaya başlayan bir yorumun ürünüdür (Greenfield, 1961).

Türkiye'deki geniş hanelerin oranı, geçmişte olduğu gibi bugün de sanayi devriminden önce kuzeybatı Avrupa'daki geniş hane oranlarından dahi yüksektir. 
Bununla birlikte geçmişte ya da günümüzde geniş aile veya çekirdek aile hanelerinin oranının birbirinden yüksek olması, geniş aile ilişkilerinin boyutu ve önemi açısından herhangi bir anlam ifade etmez. Özellikle Türkiye'de geniş aile ve çekirdek aile haneleri birbirleriyle iç içedir. 1970'li yıllarda, kırsal bölgelerdeki hanelerin üçte ikisinin, kentlerdeki hanelerin ise üçte birden fazlasının evlilik hayatına geniş aile hanesi içinde başlamış olmaları ve bir süre geniş aile hanesinde yaşamaları bu görüşü desteklemektedir (Timur, 1972, 45). Kıray'ın ve Kongar'ın 1970'li yıllarda yaptığı araștırmalar, çekirdek aile olarak yaşamalarına karşın kırsal bölgelerdeki evli kardeşlerin ailelerinin hem birbirleriyle hem de ebeveynleriyle önemli ölçüde ekonomik ve toplumsal iş birliğine girdiklerini göstermektedir (Duben, 2002, 85).

Türkiye'deki aile ve hane yapısı eğilimleri üzerine 1968'den önceki dönemde yapılan araștırmalar Türk köylerindeki hanelerde geniş aile hayatının hâkim olduğunu gösteriyordu. 1968'de ülke çapında yapılan araştırmanın sonucu ise ideal aile tipi olduğu öne sürülen ataerkil geniş ailenin toplam hanelerin yaklaşık bește birini oluşturduğunu göstermiş, bu da toplumsal bir değişim işareti olarak kabul edilmiştir. Küçük aile ișletmelerinin iş gücü fazlası ve toprak kıtlığı sorunlarından etkilendiğine işaret eden bu durum, yeni ücretli iş firsatları ve ataerkil geniş ailedeki çekişmeler nedeniyle geniş hanelerin başka biçimler aldığının kanıtıdır. $\mathrm{Bu}$ araştırmaya göre, ancak zengin köylüler kalabalık aileler şeklinde yaşamaya devam edebilmektedir. Ekonomik zorluklarla karşılaşan çoğunluk ise zorlukların üstesinden gelebilmek adına farklı tipte akrabalık ilişkileri ve geniş aile biçimleri ortaya çıkarmıştır. Örneğin, kentsel bölgelerde daha sık görülen yeni tip geniş hanelerde evin geçimi, ekonomik gücü olmayan babanın yerine evin oğlu tarafından karşılanmaktadır (Özbay, 1998, 159).

Kıray (1999) Ereğli'deki toplumsal dönüşümü yansıtan önemli araştırmalar yapmış ve aile içi ilişkilerdeki değişimleri incelemiştir. Ereğli'de bağımsız birimlerin yüzde altmıştan fazlası çekirdek ailelerden oluşmaktadır. Ancak, bu ailelerin yaklaşık yüzde sekizinde geleneksel kalıpların dışında kalan sıra dışı bir durum mevcuttur. Karı-koca ve çocuklar dışında, kadının anne ve babasının da aynı hane içinde yaşıyor olması, aile üyeleri arasındaki ilişkinin ne derece değiştiğini gözler önüne sermektedir. Soya dayalı geniş aile özelliklerinin gözlemlenmediği, ama kadın ya da erkek tarafı akrabalarla bir arada yaşayan ailelerin varlığı da hane yapısındaki değişimi gösteren başka bir örnek olarak karşımıza çıkmaktadır (Kıray, 1999, 108).

Kandiyoti (1997) atayerli geniş ailede yaşayan kadının yaşam niteliğinin, Ortadoğu'daki kadınların ikincil konumları ve bu konumları içselleştirmeleriyle ilgili önemli ipuçları verdiğine dikkat çekmektedir. Kadınların erken evlilikle erkek reisli hane halkı içine katılması, bu hanede erkek çocuklarına değer verilirken kız çocuğunun değersizleşmesi, kadın ve erkekler arasında görülen yaş hiyerarşisi, sadece İslami toplumlara özgü bir durum değildir. Hindistan, Çin gibi Asya toplumlarında da bu durumun tipik örneklerine rastlanmaktadır. Kadınların psikolojik gelişimini derinden etkileyen birçok kültürel uygulama, aralarında bazı farklar olmasına rağmen bu ülkelerde de görülmektedir (Kandiyoti, 1997, 79).

Türkiye'de 1968 yılında yapılan istatistikler, evliliklerin yüzde altmış yedisinin her iki eşin tam rızasına dayalı olarak aileleri tarafından düzenlendiğini göstermektedir. Evliliklerin yüzde on birinde kadınların rızası alınmazken, kentsel alanlarda yüzde dokuz, kırsalalandayüzde üçoranındagenççiftin kaçarak evlendiğigörülmektedir. Kız 
için uygun bir eş bulunması, ailesinin sorumluluğundadır. Günümüzün muhafazakâr toplumlarında hala süren bu uygulama yüzünden karı-koca arasında kurulması gereken duygusal bağ olușmamakta ve geniş aile yașamı içinde gelișememektedir. Karı-koca ilişkisinin göreve dayalı mesafeli niteliğine karşılık, duygusal yakınlığın dışa vurumu ancak çiftin kendi çocukları ve aynı cinsten arkadaş gruplarıyla kurduğu ilişkiler sayesinde gerçekleşmektedir (Kandiyoti, 1997, 74).

Kadınlar gelin olarak yeni bir aileye katıldıklarında, bu ailenin kadınları tarafından hemen kabul görmezler. Gelin ancak erkek çocuk doğurduğunda hanede kıdem kazanarak güç dengesini kendi lehine değiştirebilir. Asıl gücünü ise kaynana olduğunda kazanır. Bu nedenle ana-oğul ilişkisi çok önemlidir. Kadınlar ömür boyu himaye edilme beklentisiyle yetiştirilirken, erkek çocuklar aile bütçesine katkıda bulunsa da bulunmasa da aileye bağımlı olarak yetiştirilir. Evlendikten sonra karşılaşılan maddi sıkıntılar, aileyle birlikte yaşamayı ya da yakın ilişki içinde bulunmayı zorunlu hale getirebilir (Kandiyoti, 1997, 80). Tüm bu bağımlılıklar ve zorunluluklar karı-koca arasında ve aileleri arasında sorunlar yaşanmasına neden olabilmektedir. Bu sorunlar genellikle gelin-kaynana anlaşmazlığı olarak ortaya çıkmaktadır.

\section{Türkiye'de ve Farklı Toplumlarda Gelin-Kaynana Rolleri}

Her toplumda farklılık gösteren davranış kalıpları, doğdukları andan itibaren insanları, aile, eğitim ve kültür vasıtasıyla içinde yaşadıkları çevreye uygun bir birey haline getirmek üzere çalışmaya başlar. Toplumsallaşma olarak adlandırılan bu süreç içinde her birey, aile ve akrabalık ilişkileri de dahil olmak üzere içinde yaşadığı kültüre özgü davranış kalıplarını öğrenir ve uygular. Dünyanın farklı coğrafyalarında yer alan toplumlarda birbirinden farklı ya da birbirine benzer akrabalık ilişkilerine rastlanabilir.

Asya ve Ortadoğu'da bulunan ataerkil toplumlar ile Türkiye'nin geleneksel bölgelerindeki gelin-kaynana ilişkileri arasında yakın bir benzerlik kurulabilir. $\mathrm{Bu}$ toplumlarda yaşayan kayınvalideler gelinlerine karşı baskıcı bir tutum sergilemektedir. Çinli bir kadın, eşine, çocuklarına ve eşinin ailesine hizmet etmenin yanı sıra evliliğin ilk yıllarından itibaren eşinden çok kayınvalidesiyle vakit geçirmek zorundadır. Çin'de yaşlılık önemli bir erdem olarak görüldügü için yaşlılar gündelik pratiklerle ilgili kuralları belirleme hakkına sahiptir. Yaşlılara tanınan bu ayrıcalık, onların gelinleri üzerinde kurdukları otoriterve baskıcı tavırları meşrulaștırmaktadır (Yan Du, 2013, 178).

Shih ve Pyke'ın (2009: 348) Çinli Amerikalı gelin-kaynanalar arasında yaptı̆̆ı araștırma, bukadınlarınkendigüçlerinibirleștirmeyoluylaataerkil toplum kurallarına karşı durma potansiyeli taşıdığını ortaya koymuştur. Geleneksel Çin toplumunda kayınvalide otoritesi hala geçerli olmakla birlikte, gelinler kayınvalide yanındayken ona itaat etmekte, uzaktayken ise kendi seçimlerine göre davranmaktadırlar. Çinli gelinler, kayınvalideyle yaşadıkları problemleri evlilik yaşamında karşılaştıkları sorunlar arasında üçüncü sıraya koymaktadırlar.

Shih ve Pyke (2015) tarafından yapılan başka bir araştırma, ataerkil kuralların baskın olduğu Asya toplumlarında gelinlerin koca tarafının otoritesi altında yaşamak, onlara itaat etmek ve hizmet etmek zorunda olduğunu göstermiştir. Hindistan kültüründe de kadınlar eşlerinin ailesine itaat etmek zorundadır. "İyi bir kız eşinin ailesine her 
zaman hizmet etmelidir", "bir kız evlenene kadar babasının evinde misafirdir" gibi Hindistan'da sıkça kullanılan söylemler, Türkiye'nin geleneksel bölgelerinde yaygın olarak kullanılan "kız evlat misafirdir" deyişiyle aynı anlamı taşımaktadır (Aktaran: Aydın, 2017, 20).

Hindistan'da yaşayan bir kadın evlenince, kocasının evinde ve onun ailesiyle birlikte yaşamaya başlar. Yeni gelin, kayınpederine ve eşinin büyük erkek kardeşlerine saygı göstermek zorundadır. Bununla birlikte, gelin, onların yanındayken yüzünü örtmeli ve onlarla çok az konuşmalıdır. Gelin, ancak kocasının küçük erkek kardeşlerinin yanında daha serbest davranabilir. Rajputlarda gelin, ilk çocuğunu doğuruncaya kadar yüzünü kayınvalidesinden ve eltisinden saklamalıdır. Misafir geldiği zamanlarda ise gelin, kaynanasının ve eltisinin oturduğu yerden daha alçak bir yere oturarak onlara saygı göstermek zorundadır (Kırımlı, 1998, 13).

Japon kültürünü inceleyen Bozkurt Güvenç (2002) gelin-kaynana anlaşmazlığının Japonya'da olağan sayıldığını söyler. Japon aile sisteminin temelinde yer alan kök aile üç kuşağı bir arada barındıran, geniş aile formunda bir yapılanmadır. Kök aile, karı-kocayı, kocanın evlenmemiş çocuklarını, kocanın büyük oğlunu, büyük oğlun karısı ile çocuklarını kapsayan bir geniş aile olması nedeniyle gelin-kaynana arasında sorun çıkması kaçınılmazdır. Japon toplumunda kızlar gelin verilir, aileye başka soydan gelin alınır. Japonya'da kaynanası hayatta olan her evli kadın gelin olarak anılmaktadır.

Evli bir Japon kadının, iki temel görevi vardır: Kocasının ana-babasına bakmak ve kocasının soyuna çocuk doğurmak. Japonya'da kocanın yaşlı ana-babasına bakmak ailenin büyük oğluyla evlenen gelinin görevi olarak görülür. Bu yüzden, Japon ailesinin büyük erkek çocukları Japon kızları için ideal koca adayı değildir. Japon toplumunda aile başkanlığı, babadan sonra 35-40 yaşına gelen büyük oğula geçer. Aile başkanlığının büyük oğula geçmesiyle, kaynana da hane yönetiminin simgesi olan pirinç kaşığı gelinine bırakır. Ailede önemli olan karı-koca ilişkisi değil anababa ve çocuk ilişkisidir (Güvenç, 2002, 212).

Türkiye'de ise evlilik, yetişkin olmanın bir gerekliliği olarak görülmektedir. Türkiye'deki toplumsal pratikler, kültürel, kişisel ve ekonomik baskılarla bireyi evlenmeye yönlendirmektedir. Geleneksel ailenin varlığının ve devamının ön koşulu evliliktir. Bu koşul aynı zamanda ataerkil düzeninin de devamını sağlamaktadır. Geleneksel ailede anne, baba ve çocuklar birbirlerine sadakatle ve güçlü duygularla bağlıdır. Fakat bir erkeğin sadakatinin öncelikle kendi ana-babasına ve çocuklarına karşı yoğun olması beklenir (White, 1999, 65). Ana-oğul arasındaki ilişki, baba-oğul arasındaki ilişkiden daha yakındır. Bu sıcak ve yakın ilişkinin kökeninde, kadının erkek evlat doğurarak kocasının evindeki yerini sağlamlaştırmayı ve yaşlılığında oğlundan destek görmeyi garanti altına aldığı düşüncesi yatmaktadır. Türk toplumunun her kesiminde bu nedenler geçerli olmasa da erkek evlat sahibi olma isteği toplumun her kesiminde aynıdır (Delaney, 2018, 174).

Türkiye'nin geleneksel yörelerinde kadınlar, öncelikle kocaya ve ailesine karşı sorumlu olacak șekilde yetiştirilir ve erken yaşlarda evlenerek, kayınpederlerin reis olduğu ailelere gelin olarak giderler. Kızların erken yașta evlendirilmesi, kocaya ve kocanın ailesine boyun eğmelerini kolaylaştırır. Gelinlerin baba soylu aile içindeki konumlarını güçlendirmelerinin tek yolu, erkek çocuk sahibi olmalarıdır. Ancak bu sayede yeni gelinlerin katlandıkları güçlükler ilerde kendi gelinleri üzerinde 
uygulayacakları otorite ve denetimle yer değiştirecektir. Bu düşünce tarzı, ataerkil değerlerin içselleştirilmesini ve yeniden üretilmesini sağlar (White, 1999, 67).

Türkiye'nin geleneksel bölgelerinde yaşayan aileler çocuklarının eş seçiminde söz sahibi olmaya devam etmektedir. Kayınvalidelerin görücü giderek oğullarına eş seçmeleri eskiye oranla azalmış olmakla birlikte, erkek ailesi her zaman gelin alan taraftır. Türkiye'de ister geleneksel ister modern kesime dahil edilen ailelerde olsun aynı söylem geçerlidir. Kız alınır ya da kız verilir. Oğlan vermek gibi bir kavramsallaştırma mevcut değildir. Eși ve eşinin ailesi tarafından seçilen olmak, kadının aileye ve kocasının ailesine bakış açısını önemli derecede etkiler. Ataerkil düzende erkekler, seçilmedikleri ve soyadlarını değiştirmedikleri için kendilerini evlilik yoluyla dahil oldukları yeni akrabalık ilişkilerine uyum göstermek zorunda hissetmezler (ÇamoğluYakalı, 2017, 37). Bu nedenle, kadının ve erkeğin aileye ve evlilik yoluyla edinilen akrabalık ilişkilerine bakış açıları birbirinden farklıdır. Evlenen kadın, yeni girdiği aileye uyum gösterme zorunluluğu duymakta ve özellikle kayınvalidesi tarafından kabul edildiğini hissetmek istemektedir. Gelinlerin, kayınvalideleri tarafından kabul edilmesi veya edilmemesi, pek çok kültürel faktörle ilişkilendirilebilir.

\section{Araştırmanın Yöntemi}

Gelin-kaynana iletişiminin niteliğini belirleyen kültürel faktörleri belirlemek amacıyla yapılan bu araştırmada niteliksel araştırma yöntemleri kullanılmıştır. Bireysel farklılıkları ve bireyin çevresiyle ilişkisini önemseyen niteliksel yöntemin temelinde, her bir ilişkinin kendine özgü olduğu, hiçbir şeyin birbiriyle eşit olamayacağı ve bağlamından ayrı değerlendirilemeyeceği düşüncesi yatar. Bir yanıyla bütüncül, diğer yanıyla ayrıntıcı olan nitel düşünce, bütünün ayrıntılardan oluştuğunu ve her bir ayrıntının, bütünün niteliğini belirleyen bir bileşen olduğunu kabul eder. Bir sosyal olayın nitel düșüncenin ıșığı altında incelenmesi, hem bir bütün olarak dışarıdan nasıl göründüğünü hem de olaya katılan bireyleri ilgilendiren yanıyla içeriden nasıl göründüğünü anlamayı kolaylaștırır (Kartarı, 2017, 211).

Nitel araştırmanın herkes tarafından kabul edilen bir tanımını yapmak güç olmakla beraber, "nitel araştırma, kuram oluşturmayı temel alan bir anlayışla sosyal olguları bağlı bulundukları çevre içinde araştırmayı ve anlamayı ön plana alan bir yaklaşımdır" denilebilir (Yıldırım ve Şimşek, 2013, 19). Nitel yaklaşım, araștırma konusuyla ilgili verilerin tam yapılandırılmamış tekniklerle toplanmasını vurgular. Niteliksel araştırmalarda kullanılan bütün teknikleri içeren etnografi ise bir insan grubunu ya da bir grubun kültürünü anlama ve betimleme çabası olarak tanımlanabilir. Nitel düşünceye dayalı bir etnografi çalışması, araştırılan grubun kültürünü, bileşenlerini ve arasındaki ilişkileri, o kültüre mensup kişilerin gözünden görerek anlamayı içerir. Araştırılan grubu anlamak için o grubun kullandığı iletişim kodlarını anlamak gerekir ki, kültür ve iletişim arasındaki temel bağlantı tam bu noktadadır (Kartarı, 2017, 217).

Antropologlar tarafından geliştirilen etnografik araştırma, antropolojik alan çalışması olarak da bilinir. Etno (insan) ve grafi (tanımlamak, tasvir etmek) kelimelerinden oluşan etnografi, davranışları doğrudan gözlemlemeyi ve bu gözlemlere bağlı olarak tanımlamayı esas alan bir araştırma biçimidir. $\mathrm{Bu}$ araştırmalarda gözlenen grup üyeleriyle doğrudan bağlantı kurulur ve araştırmaya katılan kişilerin düşünceleri ve davranışları kültürel bağlam ile ilişkilendirilerek açıklanmaya çalıșılır (Yazıcı ve diğerleri, 2012, 652). 
Nitel düşünceye dayalı bir etnografi çalışması olan bu araştırmanın bulguları araştırma grubuna dâhil edilen gelin ve kayınvalidelerle tek tek derinlemesine görüşme yaparak elde edilmiştir. Önceden belirlenen bir amaç için yapılan, soru sorma ve yanıtlama tarzına dayalı, etkileşimli bir iletişim süreci olarak tanımlanan derinlemesine görüşme, sosyal bilimlerde en sık kullanılan araştırma tekniklerinden biridir. Yapılandırılmış ve yapılandırılmamış olmak üzere iki görüşme türü vardır. Yapılandırılmış görüşmede amaç, görüşülen bireylerden toplanan bilgiler arasındaki benzerlikleri ve farklılıkları saptayarak karşılaştırma yapmaktır. Yapılandırılmamış görüşmede ise önceden belirlenmiş bir soru ve yanıtlara ilişkin bir beklenti söz konusu değildir. $\mathrm{Bu}$ araştırma için yapılandırılmış açık uçlu görüşme soruları hazırlanmış ve görüşülen her kadına aynı şekilde sorulmuştur. Bu uygulama, görüşmeci yanlılı̆̆ını veya öznelliğini azaltan bir özelliğe sahiptir. Aynı soruların araștırmaya katılanlara aynı șekilde sorulmasıyla elde edilen veriler, araștırmacının bu verileri karşılaştırmasını, sınıflandırmasını ve elde ettiği bulguları analiz etmesini kolaylaştırır (Yıldırım ve Şimşek, 2013, 96).

Niteliksel araştırmalarda kullanılan derinlemesine görüşme tekniği gündelik yaşama dair olup araştırmaya değer bulunan olgu, olay, süreç ve ilişkilerin özüne inmeyi, bunların ayrıntılarını bütüncül olarak anlamayı mümkün kılan bir veri toplama tekniğidir. Araștırılan konuya odaklanmayı kolaylaștırmasının yanı sıra, görüşülen kişilerin kişisel görüş, düşünce ve değerlendirmelerini bir araya getirerek doğrudan gözlenemeyen, bazen davranışlara dahi yansımayan niyet ve beklentilerin ortaya çıkarılmasını sağlar. Gündelik konuşmalardan farklı olarak araştırmanın konusuna ve amacına bağlı olarak gerçekleştirilen derinlemesine görüşme, görüşülen kişilerin kendilerini kuşatan sosyal çevreyi ve çevrelerindeki insanları nasıl değerlendirdiklerini ortaya koyma firsatı verir (Kümbetoğlu, 2005, 72).

Araştırmanın örneklemi, amaçlı örnekleme yöntemlerinden biri olan ve araştırmaya hız kazandıran kolay ulaşılabilir (covenient) durum örneklemesine uygun olarak oluşturulmuştur. Amaçlı örnekleme yöntemleri nitel araştırma geleneği içinde gelişen ve derinlemesine analizi ön plana alan kültür analizi (etnografya) geleneği içinde ortaya çıkmıştır. Olasılık temelli örnekleme yönteminde olduğu gibi temsiliyeti sağlama yoluyla evrene geçerli genellemeler yapma kaygısı taşımayan amaçlı örnekleme yöntemleri, olguların ve olayların keşfedilmesinde ve açıklanmasında yararlı görüldüğü için tercih edilmektedir (Yıldırım ve Şimşek, 2013, 135).

Nitel araştırma, araştırma yapılan alanın yakından incelenmesini ve mümkün ise ilk elden veri toplanmasını gerektirir. Bu nedenle araştırmacının alanı tanıması ve alanda çalışmanın getirdiği sorumlulukları yüklenmesi gerekir. Alanı yakından tanımak, görüşülen kişilerle temasa geçerek izin almak ve gerekirse araştırma mekânı yaratmak, araştırmacının yapması gereken işler arasındadır. Araştırmacı, nitel araştırmanın bu gerekliliklerini yerine getirmek amacıyla araştırma alanı olarak, tanıdığı insanların yaşadığı bir köy olan Anadolufeneri Köyü'nü tercih etmiştir. Araştırma grubunun kolay ulaşılabilir durum örneklemine uygun olarak oluşturulmasının gerekçesi ise araştırmacının o köyde yaşayan tanıdıkları vasıtasıyla görüşme yapacağı gelin ve kayınvalidelere daha kolay ulaşma düşüncesidir.

İnsanların dâhil olduğu her tür araştırmada izlenmesi gereken bazı kurallar ve etik ilkeler vardır. Günümüzde, dünyanın neresinde olursa olsun bir araştırma yapmak gerektiğinde uyulması gereken etik ilkeler, bilinçli onay, gizlilik, aldatmama ve 
verilere sadık kalma başlıkları altında toplanabilir. Bu araştırmanın her safhasında uyulması gereken etik kurallara riayet edilmiştir. Araştırmaya katılan gelin ve kayınvalidelerden bilinçli onay alınmış ve kimliklerinin gizli tutulacağı konusunda güvence verilmiştir. Görüşülen kişilere, araştırmacıya aktardıkları düşünce ve deneyimlerin akademik çalışmalarda kullanılacağı bildirilmiştir. Araştırmanın verileri, gelin ve kayınvalidelerle yapılan derinlemesine görüşmelerin araştırmacı tarafından yazıya geçirilmesi yoluyla elde edilmiştir. Gelin kaynana arasındaki uyum, uyumsuzluk, beklenti ve çatışma durumlarıyla ilgili bulgular, bu çalışmada okuyucuya aktarılan anlatılar çerçevesinde ele alınmış ve incelenmiştir. Bu çalışma, gelin-kaynana konusunu inceleyen başka araştırmacılara bir karşılaştırma yapma olanağı sağladığında hedefine ulaşmış sayılacaktır.

\section{Araştırmaya Katılan Kadınların Tanımlayıcı Özellikleri}

$\mathrm{Bu}$ araștırmaya katılan altısı gelin, altısı kayınvalide olan on iki kadın İstanbul'un Anadolufeneri Köyü'nde ikamet etmektedir. Bu kadınlardan dördü Anadolufenerli, öteki sekiz kadın ise köy dışından evlilik yoluyla bu köye gelin gelmiş olan kadınlardır. Elde edilen bulgular, bu köyde dünyada yaygın olarak görülen patrilokal (atayerli) ikamet tarzının tercih edildiğini göstermektedir. Bu ikamet tarzına göre yeni evli çift, damadın ailesinin evine ya da yakınına yerleșmektedir.

Yaşları, 48-68 arasında değişen kayınvalidelerden üçü ilköğretim mezunudur. Üç kayınvalide ise ilköğretimi bitirmemiştir. Kayınvalidelerden birinin hanesi ataerkil geniş aile özelliği göstermektedir. Bir kayınvalide, çocuklarının hepsini evlendirdiği için eşiyle birlikte yaşamaya devam etmektedir. İki kayınvalide, yine eşleri ve evlenmemiş çocuklarıyla bir arada yaşamaktadır. Altı kayınvalideden ikisi ise eşleri vefat ettiği için yalnız yaşamaktadır.

Görüşülen gelinler 22-42 yaşları arasındadır. Gelinlerden ikisi, Anadolufeneri Köyü’nde doğup büyümüş ve bu köyden bir erkekle evlenmiştir. Öteki dört gelin ise köy dışında doğup büyümüş ve Anadolufenerli erkeklerle evlenerek bu köye gelin gelmişlerdir. İki gelin ilkokul mezunu, bir gelin ortaokul terk, iki gelin lise terk, bir gelin ise üniversite terk olduğunu bildirmiştir.

Anadolufeneri Köyü'nde ikamet eden gelinlerin ve kayınvalidelerin mensup olduğu aileler düşük gelir grubuna dahildir. Gelinlerin eşlerinin yalnızca dördü aylık ücretli bir işte çalışmaktadır. Diğer iki gelinin ve kayınvalidelerin eşleri, kamyonculuk, balıkçılık ve bahçıvanlık yaparak ailenin geçimini sağlamaktadır. Eşi vefat ettiği için yalnız yaşayan kayınvalidenin eşlerinden birinin yaşarken balıkçılık yaptı̆̆ı, diğerinin ise bahçıvanlık yaptığı belirlenmiştir. Görüşülen altı kayınvalidenin üç tanesi, altı gelinden ise kayınvalidesiyle aynı evde yaşayan yalnızca bir tanesi ağ örerek aile bütçesine katkı sağladığını söylemiștir. Tüccarlar tarafından köye getirilerek dağıtılan ve tatlı suda balık tutmak için kullanılan ağları örerek para kazanan kadınlar, kazanılan parayla kızlara çeyiz düzüldügünü ya da çocukların okul masraflarının karşılandığını belirtmişlerdir. Eşi aylık ücretle çalışan dört gelinin tümü, eşlerinin aldığı aylık gelir köy dışında bir ev kiralamaya yetmediği için kayınvalideleriyle yan yana veya altlı-üstlü evlerde yaşamak zorunda olduklarını söylemişlerdir.

Araștırma grubuna dâhil olan gelinlerin ve kaynanaların hanelerinden biri ataerkil geniş aile, diğerleri çekirdek aile özelliği göstermektedir. Bir çift gelin-kaynananın geniş aile içinde yaşamaya devam etmesinin nedeni, evlenen oğulun aylık gelirinin 
ev geçindirecek düzeyde olmamasıdır. Aynı köy içinde yan yana veya altlı-üstlü evlerde yaşayan gelin-kaynanalar, gün içinde "cama, kapıya çıktıkça" birbirlerini görmektedirler. Gelinler, bir misafir geldiğinde kayınvalidelerini de çaya çağırdıklarını ve kayınvalideleri temizlik yaparken ona yardım etmeye gittiklerini söylediler. Gelinler, evlerinin çok yakın olması nedeniyle bayramlarda ve kandil günlerinde önce kayınvalide ve kayınpederlerini ziyaret ettiklerini ve özel günlerde ya da bir hastalık söz konusu olduğunda, getir götür yapma, ortalık toplama ve süpürme gibi işlerin kendilerine ait olduğunu belirttiler. Yemek pişirmek, genellikle kayınvalideye ait bir iş olarak görülüyordu. Araștırmaya katılan altı gelin-kaynana içinde, altlı üstlü oturdukları halde iki gelin-kaynananın birbiriyle dargın olduğu görüldü. Geliniyle konuşmayan iki kayınvalidenin eşlerinin vefat ettiği ve geçinmek için oğullarının desteğine ihtiyaç duyduğu belirlendi.

\section{Gelin-Kaynana İletişimi ve Ekonomik Durum Arasındaki İlişki}

Araştırmaya katılan gelin-kaynanalar ile yapılan görüşmelerden elde edilen bulgular, ekonomik durumun gelin-kaynana ilişkilerinin niteliğini önemli ölçüde etkilediğini göstermektedir. Kocasının kazancının yetersizliği yüzünden kayınvalidesiyle aynı evde veya yakınlarında yaşamak zorunda kalan gelinler, kayınvalideleriyle daha uyumlu geçinmektedirler. Fakat ne kadar uyumlu geçinirlerse geçinsinler, gelinlerin ayrı eve çıkma hayali canlılığını korumaktadır. Gelinlerin anlatıları, kayınvalideyle aynı evde yaşamak zorunda kalan gelinlerin ayrı eve çıkma isteklerini açıkça göstermektedir.

\footnotetext{
O sıra ayrı ev açmaya durumumuz yoktu. Ben de fark etmez dedim. Şu anda kayınvalidemle oturuyorum ama benim hiçbir çeyizim açı değil. Hepsi kolilerde. İlerde ayrı eve çıkmayı düşünüyoruz. Ömrümün sonuna kadar otururum, şikayetçi değilim ama ilerde çıkmaya mecburuz. Çocuğun okulu, kocamın işe gidip gelmesi sorun oluyor. Bir gün çıkıcaz yani (Gelin / Zehra).
}

Başka bir gelinle yapılan görüşme ise kayınvalide yanında oturmayı kabul ederek evlenen gelinlerin evin idaresi konusunda sorunlar yaşadığını göstermiştir. Reyhan Hanım, yaşlı insanları sevmesine ve onlarla iyi geçinmesine güvenerek, kayınvalide ve kayınpeder yanına gelin gitmeyi kabul ettiğini söylemiş, fakat beraber yaşamaya başlar başlamaz kayınvalidenin aile bütçesinin kontrolünü bırakmaması yüzünden sorun çıktığını şu sözlerle aktarmıştır:

O istedi ki beni hegemonya altına alsın, onun ayakları altında sürdüreyim hayatımı.
Yani hep ondan kaynaklandı. Bütçe onun elinde olacak, açık açık yaptı bunu. O yapacak
alış-verişi, ona verilecek para. Olmaz ki ama senin bundan sonra bakıma ihtiyacın var.
Abdestini al, namazını kıl, gezin. Ben bunun gibi yaşlı görmedim. Direktifi hep o verecek,
hep onun dediği olacak (Gelin / Reyhan).

Ekonomik kontrolü elinde tutmak isteyen kayınvalidelerin yanı sıra oğullarının maddi yardımına muhtaç olan kayınvalidelerin de gelinleriyle çatışma yaşadığı görülmektedir. Görüşülen gelinlerden biri, üç oğlu olan kayınvalidesine balıkçılık yapan oğullarının baktığını söyledi. Melek Hanım, evlendikten sonra kayınvalidesiyle arasında çıkan sorunlar yüzünden köy dışına taşınmak istediğini, eşine balık tutmaktan vazgeçip balık satmayı önerdiğini de anlattı. Fakat kayınvalidesi izin vermediği için köyden taşınamayan Melek Hanım, dargın oldukları halde kayınvalidesiyle bitişik evlerde yaşamaya devam etmektedir.

Allah onu ıslah etsin. 0 ne yaptıysa bilinçli yaptı. Kocasına da yaptırıyordu İstediği her şeyi. Bağırır çağırır, küçük görür, sen adam mısın gibi laflar. Öldü de kurtuldu adam yani. 
O kendi çocuklarını bile çocuğu gibi görmüyor. Tek derdi, çocukları ona para getirsin. Tek gördüğü şey para (Gelin / Melek).

Araştırma grubundaki altı kayınvalideden, erkek çocuklarının bakımına ihtiyaç duyan iki kayınvalidenin, gelinleriyle dargın olmaları dikkat çekici bir noktadır. $\mathrm{Bu}$ iki örnek göstermektedir ki erkek çocuklarının maddi desteğine muhtaç olan kayınvalidelerin gelinleriyle aralarında sorun çıkmaktadır. Oğulların maddi ve manevi bakımına muhtaç olan ve gelinleriyle konuşmayan kayınvalidelerden biri ekonomik durumu hakkında şunları söylemektedir:

Benim hiçbir şeyim yok. Rahmetli sağken küçük oğluma verdi tapıyı. Üst kat küçügün, alt kat büyüğün ama ben oturuyorum şimdi. Oğullarım bakıyor bana. Kocam sağken de çocuklarım bakıyordu bize. Çünkü kocam rençperdi benim, maaşımız falan yoktu. Son on yıldır kocam hastaydı. Hep oğullarım baktı bize (Kayınvalide / Emine).

\section{Gelin-Kaynana İletişiminde Tartışma Yaratan Nedenler}

Kayınvalidelerin gelinlerin hayatına müdahale etmesi, gelin-kaynana ilişkisinde sorun yaratan en önemli konulardan biridir. Kadınların karşılıklı olarak birbirine karışması veya karışılmasına izin vermemesi, iki kadın arasındaki en çetin mücadele alanlarından biridir. Bu araştırma, gelin-kaynana arasında tartışma ve hatta dargınlık yaratan sorunların müdahaleci kayınvalideler yüzünden ortaya çıktığını göstermiştir. Kayınvalidelerin gelinlerini kendi otoriteleri altına almak istemeleri ve ayrı evde yaşıyor olsalar bile temizlik işlerinden çocuk bakımına kadar pek çok konuda geline müdahale etmeleri, iki kadın arasında sorun çıkmasına neden olmaktadır.

Kayınvalidesinin küçük gelini olan Nergis Hanım, evliliğinin ilk yıllarında kayınvalidesinin özel hayatına müdahale etmesi yüzünden sıkıntılı günler geçirmiştir. Eltisinin kızıyla yaşıt olduğunu ve çok iyi arkadaş olduklarını söyleyen Nergis Hanım, kendi aralarında kıyafet değiş tokuşu yaptıkları için kayınvalidesinin kendisini azarladığını ve bu yüzden tartıştıklarını anlatmıștır. Kayınvalidesinin kılık kıyafet ve yiyecek içecek israfı konusunda çok titiz davrandığını belirtmiş ve aralarında geçen tartışmadan sonraki durumu şöyle özetlemiştir:

\footnotetext{
Benim evim ayrı, barkım ayrı, bana karışamazsın demiştim ona. Sonra birkaç gün konușmamıștık. Ama o oldu, benim kayınvalidem bir daha benim gelenime gidenime, giydiğime çıkardığıma, aldığıma ettiğime hiçbir şeyime karışmadı. Yalnızca müsrifliğe kızar. Aldığın şeyi temiz kullan, yiyeceğin kadar pişir, dökme der. Bir yemek kaldığı zaman, dökerken hala korkarım kayınvalidem görürse diye (Gelin / Nergis).
}

Kayınvalide yanına gelin gelen Reyhan Hanım ise evlendiğinden beri kayınvalidesiyle çatışma yaşadığını ve artık konuşmadıklarını söylemiştir. Kayınvalidesinin dügünden sonra sadece üç gün eşiyle baş başa kalmasına izin verdiğini, beraber yaşamaya başladıktan sonra da her konuda kendisine müdahale ettiğini anlatmıștır. Evlendikten üç ay sonra bile oturduğu evin anahtarının kendisine verilmediğini, pişirdiği yemeklerin kayınvalidesi tarafından beğenilmeyip çöpe döküldüğünü, aile bütçesinin ve evin kontrolünün hiçbir şekilde kendisiyle paylaşılmadığını söyleyen Reyhan Hanım, karşılaștıkları ilk günden itibaren kayınvalidesi tarafından sevilmediğini düşünmektedir.

Biz evlendikten üç gün sonra telefon ediyor, evimi özledim diyor. Eşimle beraber gittik aldık onları ağabeyinin evinden. Daha orada beni haşlamaya başladı. Ben bir sigara yakar yakmaz, zamane gençleri, şimdi kimseye bakmıyorlar, yakıyorlar sigarayı' dedi. Herkesin içinde söyledi bunu. Ben orda çok bozuldum (Gelin / Reyhan). 
Kayınvalidesiyle konuşmayan bir başka gelin ise eşiyle evlenmesinde kayınvalidesine duyduğu sevgi ve hayranlığın büyük payı olduğunu fakat evlendikten sonra kayınvalidesini bir cadı gibi görmeye başladığını söylemiştir. Melek Hanım, evlendikten sonra kayınvalidesinin ev işinden çocuk bakımına kadar her konuda kendisine müdahale etmeye ve yaptığı işleri beğenmemeye başladığını anlatmıştır. Annesine gitmek istediğinde bile önce kayınvalidesine danışmak zorunda kaldığını, hatta kocasından izin alsa da gideceği yere kayınvalidesi olmadan gidemediğini, günlük olayları ve küçük sorunları abartarak eşine aktardığını, bu nedenle çok zor yıllar geçirdiğini ve sinir hastası olduğunu söylemiştir.

Çöpleri bile araştırırdı yemek dökmüş müyüm diye. Her şeyi eşime anlatır, onu doldururdu bana karşı. $O$ da annesi ve kendi aile çevresi yüzünden bana hücum ediyordu, çok ağır şeyler oluyordu. Deli gibi olmuştum böyle her şeyden korkuyordum. 0 cadıdan korkuyordum. Cadı diyorum ben ona. Hala onun yüzünü göreyim içim ürperiyor (Gelin / Melek).

Müdahaleci bir kayınvalide olduğu anlaşılan Yeter Hanım ise üç gelin sahibi olduğunu fakat iki gelinin kendisiyle konuşmadığını söylemektedir. Gelinlerine her konuda yardımcı olduğu halde onlar tarafından takdir edilmediğini anlatmış, sadece gelinlerinden birini temiz ve titiz olduğu için sevdiğini söylemiştir. Yeter Hanım'a göre ortanca gelin çok dağınık ve müsrif, küçük gelin ise çok pis ve uykucu bir kadındır.

Ben elimi uzatmasaydım, küçük gelin de bakamayacaktı çocuğuna. Bir gün baktım takır tukur sesler geliyor. Oğlum da balıkta. Bir baktım ki gelin uyuyor, o ufacık çocuk kalkmış, sobanın başında külleri dışarı çıkartmış oynuyor. Üstü başı kül içinde çocuğun. Annesi uyuyor. O kadar ağır uykusu. Çocuğunu bile emziremiyor uyumaktan. Çocuk büyümüyor diye hazır mamalar vermeye başladık. Onu da öyle kurtardık. Bu uykusu ağır diye bakamadı çocuğuna. Büyük gelinden çok çektim zaten. Hep kanamalı, hep hastaydı. $\mathrm{O}$ da çocuğuna bakamadı. Ortancanın çocuğu olmadı. Kim bilir o nasıl bir anne olacaktı (Kayınvalide / Yeter).

\section{Kayınvalidelerin Tutum ve Davranışlarının Gelinler Üzerindeki Etkileri}

Kayınvalidelerin tutum ve davranışları, gelin-kaynana arasındaki iletişimin niteliğini önemli ölçüde etkilemektedir. Gelin-kaynana arasındaki duygusal iletişimin içeriği onların sonraki ilişkilerini şekillendirmektedir. Kayınvalidelerin baskıcı davranışları gelin-kaynana arasındaki iletişimi olumsuz etkilerken, sevecen davranışlar bu iki kadın arasındaki iletişimi olumlu yönde etkilemektedir. Kayınvalidesiyle çok iyi geçindiğini söyleyen Zehra Hanım'ın anlattıkları bu hassas noktanın anlaşılması açısından önemlidir. Eşiyle severek evlendiğini söyleyen Zehra Hanım, okul yıllarında başlayan bu arkadaşlığın kendi ailesi tarafından büyük bir tepkiyle karşılandığını, hatta bu yüzden annesinden ve ağabeyinden çok dayak yediğini söylemiştir. Evliliğini ve mutluluğunu kayınvalidesine borçlu olduğunu düşünen Zehra Hanım'ın kayınvalidesinin sergilediği davranışlardan olumlu yönde etkilendiği görülmektedir.

\footnotetext{
Düğün gecesi otobüsle buraya geldik. Bizi o gece yalnız bırakacaklardı burada. Kayınvalidem bize yemek hazırlayıp öyle gitmişti. Onu hiç unutamam. Mecbur mu yoo değil. Çok hoşuma gitmişti. Bir de üşüdüm diye üstüme hırkasını vermesini unutamıyorum hiç. Gelinlikle çok üşümüştüm. Kendi hırkasını üstünden çıkarıp bana giydirmişti. Kendisi donmuştu yani. Mesela düğünde hiç ağlamamıştım el öperken, çıkarken, ama o hırkayı bana verince çok duygulandım. Ağladım. Beni sevdiğini o zaman çok hissettim (Gelin / Zehra).
} 
Zehra Hanım'ın kayınvalidesinin ılımlı ve sevecen tutumu sayesinde gelin-kaynana arasında kurulan bu güzel ilişkinin, oğlu görücü usulüyle evlenen Emine Hanım ile gelini arasında kurulamadığı görülmektedir. Emine Hanım, oğlunun geliniyle bir aracı kadın tarafından tanıştırıldığını ve ancak onlar evlenmeye karar verdikten sonra gelinini gördügünü söylemiştir. Gelini gördüğünde hiç beğenmediğini fakat oğlunun, 'sizlerle beraber oturmayı kabul ediyor' demesi üzerine bu evliliğe ses çıkarmadığını söyleyen Emine Hanım, aynı evde yaşamaya başladıktan hemen sonra aldığı ve yaptığı hiçbir şeyi gelinin istemediğini ve kendisini kıskandığını düşündüğünü söylemiş ve dügün günü hissettiklerini șöyle özetlemiştir:

\begin{abstract}
Kibar bir hali yoktu. Delişmen bir hali vardı. Dügün günü ben sülaleme gülücük saçtım hep millet anlamasın diye. Sülalem bana 'bu deliyi nasıl aldın sen, çocuğu mahvettin' dediler. Deli deli yılışık hareketleri vardı. İçimden hep düşündüm ben bununla napıcam diye. Heralde çocuğum onu idare eder dedim. Olmadı işte, geçinemedik (Kayınvalide / Emine).
\end{abstract}

Emine Hanım'ın gelininin söyledikleri ise ilkgünden itibaren kayınvalidesi tarafından istenmediğini anladığını göstermektedir. Reyhan Hanım, evlendiği günden itibaren kayınvalidesinin her konuda müdahalesiyle karşılaştığını söylemiş ve ailece geçirilen ilk akşamda kendisini nasıl dışlanmış hissettiğini şöyle aktarmıştır:

\begin{abstract}
Oturduk televizyonlu odaya. Kayınvalidem üçlü koltuğa uzattı bacaklarını böyle. Kaynatam uzattı bacaklarını ötekine. Kocam geçti şu koltuğa oturdu. Bana kapı yanında bir yer kaldı. Televizyonu göremiyorum. Televizyon önemli değil, konuşmaları hep kendi içinde, giremiyorum konularına. Ben böyle dışlandım kaldım. Eşim bunu hissetti. Birkaç gün böyle geçtikten sonra eşim getirdi öbür televizyonu buraya kurdu. Artık siz burda seyredeceksiniz biz orda dedi annesine babasına. Tam bir haftalık evliydik o zaman (Gelin / Reyhan).
\end{abstract}

Melahat Hanım'ın anlatısı da gelin-kaynana arasındaki iletişimin olumlu ya da olumsuz yönde gelişmesinin kayınvalidelerin tutumuna bağlı olduğunu açıç̧a göstermektedir. Geliniyle arasında sorun çıkmaması için hiçbir konuda ona müdahale etmediğini, hatta gelini tarafından kendisine yapılan müdahalelere ses çıkarmadığını söyleyen Melahat Hanım, iyi geçinmek için kayınvalidelerin sabırlı ve hoşgörülü olması gerektiğini düşünmektedir. Oğlunu seven her annenin de bu şekilde davranması gerektiğine inanmaktadır. Melahat Hanım, gelinin her gelişinde, ev yeni temizlenmiş olsa bile evi silip süpürdügünü, raflardaki temiz tabak ve bardakları alıp tekrar yıkadığını söylemiştir. Gelinin yine gelir gelmez iş yapmaya başladığı bir gün "ev temiz kızım, otur iki lakırdı edelim" demesine karşılık, gelinin "senin içine çökmüş pislik" diye cevap vermesine çok üzüldüğünü, daha sonra bu olayı kızına aktarırken ağladığını ama yine de gelinine veya oğluna bu konuda bir şey söylemediğini anlatmıştır.

Mesela mutfaktaki temiz bardakları indirir yıkar. Ben ona desem ki 'kızım ben onları şartlamışım koymuşum oraya' desem aramızda dargınlık olur. Demek beni biraz aşağı görüyor, kendini çok temizmiş gibi görüyor. Öyle bir duygusu var yani. Olabilir insanlık hali (Kayınvalide / Melahat).

Melahat Hanım, gelinlere sevgi ve anlayış göstermeyi kayınvalidelerin sorumluluk alanında gördüğü için kendi geliniyle olan ilişkisinde çatışma değil uyum sağlama yolunu seçmiştir. Nitekim bir sonraki bölümde, gelinine anlayışlı davranarak hem oğlunun üzülmesini önlediğini hem de sorun yaşanmaması konusundaki hassasiyetinin gelini tarafından takdir edildiğini söylemiştir. 


\section{Kayınvalidelerin Gelinleriyle İIgili Düşünceleri}

Kayınvalidelerin gelinlerine karşı kendilerini sorumlu hissedip hissetmedikleri ve gelinleriyle ilgili düşünceleri sorulduğunda alınan cevapların gelin-kaynana arasındaki ilişkinin niteliğiyle ilgili önemli ipuçları içerdiği görülmüştür. Örneğin, geliniyle sıcak ve samimi bir gelin-kaynana ilişkisi kuramamış olan kayınvalidelerden biri, kendisini geline karşı sorumlu hissetmediğini "evimiz ayrı, barkımız ayrı ne yapayım ki ben ona, belki bir arada olsak bir şeyler olur" diyerek ifade ederken, geliniyle iyi geçinen bir başka kayınvalide, "gelini hoş tutmayı" kendisine ait bir sorumluluk olarak görmektedir. Gelin-kaynana arasındaki sorumluluk alanını "sevgi ve saygı" sözcükleriyle özetleyen Melahat Hanım, sevgi ve anlayış göstermeyi kayınvalidelerin, saygı göstermeyi de gelinlerin sorumluluğu olarak gördügünü söylemektedir.

Sevgi olması lazım, sevgi. Sevgi olunca her şey bitiyor zaten, kusurlar görülmüyor. Bak gelinim uğramıyor bana, oğlum arıyor soruyor. 0 uğramamışsa bile bana 'şimdi buradaydılar oğlum' diyorum. Ben öyle ufak şeyleri yutarım. Arada oğlum üzülmesin diye ben onu basmışım bağrıma evlat diyerekten (Kayınvalide / Melahat).

Melahat Hanım, gelini ziyarete gelmediği halde oğluna "şimdi buradaydılar" dediği zamanlarda gelinin kendisini takdir ettiğini ve ziyaret etmediği için utandığını söylemiştir. Oğlunu seven her annenin, gelinini de sevmekle yükümlü olduğunu belirtmiş ve gelinden ne beklediğini şu şekilde özetlemiştir:

O sayacak, o sevemez bizi. Anası babası gibi bağrına basamaz. Ben bir saygı beklerim gelinden. Bir gelin kendinden büyüklerini sayacak. Kayınvalide sevecek ki o da sevmeyi öğrensin (Kayınvalide / Melahat).

Geliniyle aynı evde yaşayan ve iyi geçindikleri anlaşılan Fadime Hanım ise gelini kendi çocuklarından üstün tutmaya çalıştığını söylemiştir. Gelinin istek ve ihtiyaçlarını karşılamakla yükümlü olduğuna inanan kayınvalidelerden biri olarak düşüncelerini şöyle aktarmıştır:

Bir şey alamam edemem diye üzülürüm. Görürsün bir eksiği var veya bir şey gördü, 'ayy şu ne kadar güzel' dedi mi almaya gayret ederim. Alamazsam üzülürüm, içime dert olur. Memnun etmek isterim, gönlü hoșnut olsun isterim (Kayınvalide / Fadime).

Gelin-kaynana arasındaki en önemli şeyin karşılıklı saygı ve sevgi olduğunu düşünen kayınvalidelerden biri de Adalet Hanım'dır. Gelinini kendisine iş yapmakla yükümlü görmeyen Adalet Hanım, gelinden sadece saygı ve sevgi beklemektedir. Gelini kendi evini her gün silip süpürdüğü için "kızım canına yazık değil mi?" diye uyardığını, onun yorulmasını ve sıkılmasını dahi hiç istemediğini söylemiştir. Bununla birlikte gelin kendisini kayınvalideye iş yapmakla sorumlu hissediyor olmalı ki, her konuda Adalet Hanım'a yardımcı olmaktadır. Gelinin özverili davranışları, kayınvalidenin de ona karşı sevgi dolu bir tavır takınmasını sağlamaktadır.

Önce sevgi. Kaynana gelinini seviyorsa her şeyi hoş görecek. İnan bana onun kalbini kırıcam diye ödüm patlıyor. Tatsızlığı sevmiyorum ben. Onun kalbini kırarsam bir daha yüzüne bakmamam lazım. Onu kırdığım an bir daha sevmez o beni. Onun sevgisi benden gitmesin. 0 sevgiyi kaybederim ben düşünebiliyor musun? (Kayınvalide / Adalet).

\section{Gelinlerin Kayınvalideleriyle İlgili Düşünceleri}

Görüşmelere katılan gelinler, kendilerini kayınvalidelerine iş yapmakla yükümlü hissetmediklerini söylemekle beraber kayınvalidelerinin ihtiyacı olduğu durumlarda, kendilerinden yardım istendiği durumlarda ya da yardımcı olmak kendi içlerinden 
geldiği zamanlarda gerekeni yaptıklarını ifade etmektedirler. Kayınvalidesiyle aynı evi paylaşan Zehra Hanım, mutfak işinin kayınvalidesine, temizlik ve ortalık işlerinin kendisine ait olduğunu söylemiș ve kayınvalide yanına gelin giden kızların, gittikleri evin düzenine uymak zorunda olduğunu şöyle açıklamıştır:

Eğer ki yanında oturuyorsa, kayınvalidenin düzenine uymak zorunda gelin. Çünkü sen onun yanına geldin, sen küçüksün, sen gençsin, sen ona uyacaksın. Sen onun düzenine geldin, o senin düzenine gelmedi. Gelin-kaynana arasında bu tartışma çok oluyor yani (Gelin / Zehra)

Başlangıçta kayınvalide yanına gelen ve çok kısa bir süre içinde kayınvalidesiyle anlaşmazlığa düşen Reyhan Hanım, aynı ev içinde yaşamak ve geçinmek için gerekli olan şeyin karşılıklı anlayış göstermek olduğunu düşünmektedir:

Gelin-kaynana ilişkisinde güzelliktir önemli olan, güzellikle anlaşarak bir evi paylaşmaktır. Evde mecburiyet yoktur kesinkes. Şu şöyle mi olsun, böyle mi olsun, ben şuraya gidiyorum, sen de gelir misin veya ben gidiyorum, budur yani en basit olarak. Karşındakinin her şeyine her hareketine karışmayacaksın. Anlayışlı olacaksın. Hayat herkesin kendisine aittir. Ben öyle düşünüyorum (Gelin / Reyhan).

Sema Hanım ise kayınvalidesine gittiği zaman mecbur olduğu için değil iş yapmayı sevdiği için iş yaptığını söylemekle birlikte, bazı șeyleri de görev olarak yerine getirdiğini belirtmektedir:

Mesela sayarım onu. Şöyle bir yol boyu gittiğim zaman uğramadan geçmem. Bir görev olarak görürüm bunu. Her zaman içimden gelmiyor ama uğrarım gene. İçimden gelmediği zaman uğradığımda, yağcılık yapıyormuşum gibi geliyor. Annem gibi olmuyor yani ama ne yapalım (Gelin / Sema).

Kayınvalidesiyle çok iyi geçindiğini ve annesinden farklı görmediğini söyleyen Gamze Hanım, kayınvalidesinin çok iyi ve sabırlı bir kadın olduğunu söylemekte ve ona karşı hissettiği sorumlulukları şöyle özetlemektedir:

\begin{abstract}
Benim kayınvalidem biz nişanlandığımızda anneme ne dedi biliyor musun? 'Benim oğlum bundan sonra senin oğlun oldu, benden çıktı artık' dedi. Senin kızın da benim oldu demedi bak. Çok iyi kadındır benim kayınvalidem. Halbuki çok aksi, astığı astık kestiği kestik bir kayınvalidesi varmış. Kaç sene yaşamış onunla 'öf pöf' demeden. Şimdi ben de elimden geldiği kadar onun kalbini kırmamaya çalışıyorum. İşinde yardımcı oluyorum. Her şeylerine koşarım. Kızı nasılsa ben de öyleyim yani. Kızından daha fazla seviyor beni desem yeri var (Gelin / Gamze).
\end{abstract}

\title{
Değerlendirme ve Sonuç
}

Bu bölümde, İstanbul'un Anadolufeneri Köyü'nde yaşayan gelinler ve kayınvalidelerle derinlemesine görüşme yapılarak elde edilen bulgular değerlendirilmiș, birbiriyle iyi geçinen ve geçinemeyen gelin-kaynanalar arasındaki kültürel benzerlikler ve farklılıklardan yola çıkarak gelin-kaynana ilişkisini biçimlendiren kültürel etmenler açıklanmaya çalışılmıştır.

Araștırmaya katılan gelinlerin doğduğu ve yetiştiği sosyal çevreler karşılaştırıldığında, altı gelinden sadece ikisinin Anadolufeneri Köyü'nde doğup büyüdüğü görülmektedir. Öteki gelinler, Mahmut Şevket Pașa Köyü’nde, Beykoz'da, Zeytinburnu'nda ve Arnavutköy'de büyümüş ve bu köye evlilik yoluyla gelmişlerdir. Gelinlerin toplumsallaşma süreçlerini farklı sosyalleşme ortamlarında geçirmeleri, aile, evlilik ve akrabalık ilişkileriyle ilgili farklı bakış açılarına sahip olmalarına neden olmaktadır. Anadolufenerli gelinlerin durumu incelendiğinde ise erkek 
soya uyumu kolaylaştıran faktörlerin varlığı göze çarpmaktadır. Gelin oldukları köyde doğmuş ve büyümüş olan bu kadınlar, kayınvalideleriyle aynı sosyal çevrede yaşayan, benzer aile terbiyesi almış olan kadınlardır. Bu gelinlerden biri on yedi, diğeri on sekiz yaşındayken evlenmiştir. Dolayısıyla bu gelinlerin kayınvalideleriyle iyi geçinmelerinin temelinde aynı çevrede yetişmiş olmak ve erken yaşta evlenmiş olmak gibi iki önemli unsur yer almaktadır.

Mahmut Şevket Paşa Köyü'nde ve Beykoz'da doğup büyümüş olan gelinler de geleneksel toplum kurallarına uygun olarak yetiştirilen ve Anadolufenerli gelinlerin sahip olduğu özellikleri taşıyan kadınlardır. Bu kadınlardan biri, eşinin ekonomik yetersizliği yüzünden kayınvalidesiyle aynı evi paylaşmaktadır. Bu gelinin, kocasının ailesine uyumlu olmasını sağlayan șey, ekonomik yetersizliğin yanı sıra erkek soya (Patrilineal) uygun şekilde yetiştirilmiş olmasıdır. Görüşülen gelinin, evlendiği gün babasının kendisini "ölmek var dönmek yok" şeklinde "uyardığını" söylemesi, ataerkil değerlere uygun olarak yetiştirildiğini açıkça göstermektedir.

$\mathrm{Bu}$ araştırmada görüşülen iki gelin kayınvalidenin birbiriyle konuşmadığı belirlenmiştir. Kayınvalideleriyle dargın olan gelinlerin özellikleri incelendiğinde, farklı bir sosyal çevreden bu köye geldikleri, farklı aile terbiyesi aldıkları, gelinlerin eğitim durumlarının dahil oldukları ailedeki bireylerin eğitim durumlarından daha yüksek olduğu ve kayınvalidelerin, oğullarının ekonomik yardımına muhtaç olduğu görülmüştür. Ayrıca bu gelinlerden biri yirmi yedi, diğeri kırk yaşında evlendiği için erkek soya uyumu kolaylaştıran erken yaş faktörüne sahip değildir.

Anne-oğul ilişkisinin niteliği ve erkek evlattan beklentiler de gelin-kaynana iliş̧isinde önemli rol oynamaktadır. Baba oğul ilişkisinin sorunlu olması, babanın babalık rolünü yerine getirmemesi ya da hastalık ve ölüm gibi sebepler söz konusu olduğunda, anne-oğul arasındaki bağ daha kuvvetli olmaktadır. Bu araştırmada gelinleriyle dargın olan iki kayınvalideden biri eşini erken yaşta kaybettiği için, diğer kayınvalide ise eşi vefat etmeden önce dahi yıllarca hasta yattığı için oğlunun maddi ve manevi desteğine ihtiyaç duymuştur. Gelinleri ve oğulları üzerinde baskı uygulayan ve ortaya çıkan çatışma sonucu gelinleriyle darılan kayınvalideler, oğullarının maddi ve manevi desteğine muhtaç olan kadınlardır. Kayınvalidelerin aşırı kontrolcü ve müdahaleci tavırlarının temelinde yalnız kalma korkusunun yattığı söylenebilir.

Eşinin ekonomik yetersizliği yüzünden köy dışında bir ev tutup taşınamadığı için kayınvalidesiyle aynı evi paylaşan ya da yakın oturan gelinler, kayınvalidelerine daha uyumlu davranmaktadır. Görüldüğü gibi hem anne-oğul hem de gelinkaynana arasındaki ilişkinin niteliği, ataerkil düzene özgü değerlere ne kadar önem verdikleriyle ve sahip oldukları ekonomik şartlarla yakından ilişkilidir. Erkeğin ekonomik yönden anne-babasına bağımlı olmadığı durumlarda ise gelin-kaynana ilişkisinin niteliği, her iki kadının birbirine karşı takındığı tavra göre belirlenmektedir.

Erkek soyun egemen olduğu toplumlarda gelin-kaynana arasında ana-kız ilișkisi kurulması gerektiğine inanılmaktadır. Fakat bu araştırma, sorunsuz bir gelinkaynana ilişkisi sürdüren kadınların bile birbirleriyle ana-kız olamayacaklarının farkında olduklarını ortaya koymuştur. Araştırmaya katılan kadınların anlatılarından çıkan sonuca göre, ancak kayınvalidenin hoşgörülü davranışları sayesinde iki kadın arasında yakın bir ilişki kurulabilmektedir. Bu ayrıntı, gelin-kaynana ilişkisinin anakız ilişkisi gibi olması gerektiğini dikte eden söylemin, gelinin kayınvalideye itaat etmesini sağlamak amacıyla kullanıldığını göstermektedir. 
Geline sevgi ve anlayış göstermeyi kayınvalideye ait bir sorumluluk olarak gören kayınvalideler, gelinleriyle daha iyi geçinmektedir. Gelinlerin ise gelinlik rolü olarak benimsedikleri temizlik yapmak dışında kayınvalidelerine karşı bir sorumluluk duymadıkları anlaşılmaktadır. Gelinler, ancak kayınvalideleri tarafından benimsendiklerini ve sevildiklerini hissettikleri zaman kendilerini daha uyumlu olmaya zorlamaktadırlar. Özellikle küçük yaşta evlenen gelinler, katıldıkları yeni aile ortamına alışmaya çalışırken kayınvalidelerin anlayışlı davranması gerektiğini, bu anlayışa karşılık olarak kendilerini daha uyumlu ve saygılı davranmak zorunda hissettiklerini belirtmişlerdir.

Kayınvalidelerin oğullarına duydukları sevgi ve bağlılık, gelinlerine karşı hoş görülü davranmalarında önemli rol oynamaktadır. Bu araştırmada açıkça ortaya konan bu ayrıntı, gelinleriyle dargın olan kayınvalidelerin oğullarını sevmediği anlamına gelmez kuşkusuz. Ancak, oğullarını kaybetme korkusuyla yanlış bir strateji izlediklerini düşündürür. Kayınvalidenin oğluna duyduğu sevgiyle, geline iyi davranması arasındaki bağlantının temelde "oğlunun üzülmemesi" ile ilişkili olması, akla yine erkek egemen topluma özgü değerleri getirmektedir. Fakat bu defa annenin oğluna aşırı önem vermesi dolayısıyla gelin olan kadının ezilmesi değil değer görmesi durumu ortaya çıkmaktadır.

Sonuç olarak, gelin-kaynana iletişiminin niteliği öncelikle bu iki kadının erkek soya ne kadar uyumlu yetiştirildikleriyle ilgilidir. Buna ilave olarak, ekonomik durum, eğitim düzeyi ve kadınların yetiştikleri ortam içinde edindikleri önyargılar, gelinkaynana iletişimini olumlu ya da olumsuz yönde etkileme potansiyeli taşımaktadır.

\section{Kaynakça}

Allport, G.W. (1954). The Nature Of Prejudice.. New York: Addison-Wesley.

Aydın, E. (2017). Anne-Oğul Bağlanmasının Gelin-Kayınvalide İlişkisi ve Evlilik Doyumunu Yordamadaki Rolü. Yüksek Lisans Tezi. Marmara Üniversitesi. İstanbul.

Coşgun, Ş. (2004). Kültürlerarası İletişim Sürecinde Kalıp Düşüncelerin ve Önyargıların Rolü: Antalya'da Yaşayan Güneydoğulular ile Antalya Yerlileri Arasındaki Kalıp Düşünceler ve Önyargılar. Yüksek Lisans Tezi. Ankara Üniversitesi. Ankara.

Çamoğlu-Yakalı, D. (2017). Kaynana Ne Yaptı, Gelin Ne Dedi? Ailedeki Kadınlar ve İlişkileri. İstanbul: İletişim Yayınları.

Güvenç, B. (2002). Japon Kültürü. İstanbul: Türkiye İş Bankası Kültür Yayınları.

Güvenç B. (1999). Ínsan ve Kültür. İstanbul: Remzi Kitabevi.

Hall, E. T. ve Hall, M. R. (1983). Hidden Differences Studies in International Communication. Hamburg: Stern Magazine.

Kıray, Mübeccel B. (1999). Annelerin Yeni Rolleri: Türkiye'nin Küçük Bir Kasabasında Değișen Aile-içi İliş̧kiler. Seçme Yazılar. Ankara: Bağlam Yayıncılık.

Cheal, D. (2002). Sociology of Family Life. New York: Palgrave.

Delaney, C. (2018). Tohum ve Toprak. İstanbul: İletişim Yayınları.

Yan Du, D. (2013). Living Under The Same Roof: A Genealogy of The Family Romance Between Mother-in-Law and Daughter-in-Law in Modern Chinese Hi/story. Gender \& History, 25(1), 170-191. 
Duben, A. (2002). Kent Aile Tarih. İstanbul: İletişim Yayınları.

Greenfield, S. M. (1961). Industrialization and the Family in Sociological Theory. American Journal of Sociology, 67(3), 312-322.

Kandiyoti, D. (1974). Some Social Psychological Dimensions of Social Change in a Turkish Village. British Journal of Sociology, 15, 47-62.

Kandiyoti, D. (1997). Cariyeler Bacılar Yurttaşlar. İstanbul: Metis Yayınları.

Kartarı, A. (2017). Nitel Düşünce ve Etnografi: Etnografik Yönteme Düşünsel Bir Yaklaşım. Moment Dergi. Hacettepe Üniversitesi İletişim Fakültesi Kültürel Çalışmalar Dergisi, 4(1), 207-220.

Kartarı, A. (2001). Farklılıklarla Yaşamak. Ankara: Ürün Yayınları.

Kırımlı, Y. (1998). Köyde Sosyal Organizasyon ve Sıhri Hısımlık İlişkileri. İstanbul: İstanbul Üniversitesi Yayını.

Kongar, E. (1976). İmparatorluktan Günümüze Türkiye’nin Toplumsal Yapısı. İstanbul: Cem Yayınevi.

Kümbetoğlu, B. (2005). Sosyolojide ve Antropolojide Niteliksel Yöntem ve Araştırma. İstanbul: Bağlam Yayıncılık.

Murdock, G. P. (1949). Social Structure. New York: Macmillan.

Özbay, F. (1998). Türkiye'de Aile ve Hane Yapısı: Dün, Bugün, Yarın. 75 Yılda Kadınlar ve Erkekler. İstanbul: Tarih Vakfı Yayınları.

Shih, Y. K. ve Pyke, K. (2009). Power, Resistance, and Emotional Economies in Women's Relationships with Mothers-in-Law in Chinese Immigrant Families. Journal of Family Issues, 31(3), 333-357.

Shih, Y. K. ve Pyke, K. (2015). Seeing Mothers-in-Law Through The Lens of The Mothering Ideology: An Interview Analysis of Taiwanese, Taiwanese American, and Mexican American Daughters-in-Law. Journal of Family Issues, 37(14), 1-26.

Taylor, S. E., Peplau, L. A. ve Sears, D. O. (2015). Sosyal Psikoloji. Ankara: İmge Kitabevi.

Tezcan, M. (2000). Türk Ailesinin Antropolojisi. Ankara: İmge Kitabevi.

Timur, S. (1972). Türkiye'de Aile Yapısı. Ankara: Hacettepe Üniversitesi Yayınları.

Uygur, N. (1996). Kültür Kuramı. İstanbul: Yapı Kredi Yayınları.

White, J. B. (1999). Para ile Akraba, İstanbul: İletişim Yayınları.

Yazıcı, H., Reisoğlu, S. ve Altun, F. (2012). Etnografik Araştırmacının Değerleri İle Araştırma Yöntem Ve Sonuçları Arasındaki İlişki. Batman Üniversitesi Yaşam Bilimleri Dergisi, 1(1), 649-657.

Yıldırım, A. ve Şimşek, H. (2013). Sosyal Bilimlerde Nitel Araştırma Yöntemleri. Ankara: Seçkin Yayıncılık. 